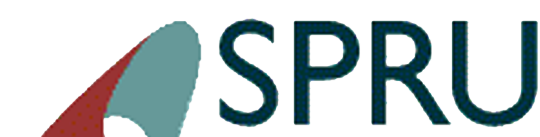

Science Policy Research Unit
Working Paper Series

SWPS 2014-13

July, 2014

\title{
Innovation as Growth Policy: \\ the challenge for Europe
}

Mariana Mazzucato

Carlota Perez 


\section{SPRU Working Paper Series}

The SPRU Working Paper Series aims to accelerate the public availability of the research undertaken by SPRU-associated people of all categories, and exceptionally, other research that is of considerable interest within SPRU. It presents research results that in whole or part are suitable for submission to a refereed journal, to a sponsor, to a major conference or to the editor of a book. Our intention is to provide access to early copies of SPRU research.

\section{Editors}

Tommaso Ciarli

Daniele Rotolo

\section{Associate Editors}

Florian Kern

Paul Nightingale

Matias Ramirez

Joe Tidd \&

Carlos Sato

Maria Savona \&

Mariana Mazzucato

Andrew Stirling Transitions

Caitriona McLeish

Civil military interface

Area

Energy

\section{Contact}

T.Ciarli@sussex.ac.uk

D.Rotolo@sussex.ac.uk

F.Kern@sussex.ac.uk

P.Nightingale@sussex.ac.uk

Matias.Ramirez@sussex.ac.uk

J.Tidd@sussex.ac.uk

C.E.Y.Sato@sussex.ac.uk

M.Savona@sussex.ac.uk

M.Mazzucato@sussex.ac.uk

A.C.Stirling@sussex.ac.uk

C.A.McLeish@sussex.ac.uk

J.Lieu@sussex.ac.uk

Administrator

Jenny Lieu

\section{Disclaimer}

The works available here are the responsibility of the individual author(s) and do not necessarily represent the views of other SPRU researchers. As matters of policy and practice, SPRU does not endorse individual research contributions.

\section{Guidelines for authors}

Papers shall be submitted in pdf or Word format. They should contain a title, an abstract, and keywords. Papers should be submitted to one of the Editors, who will process them and send them to the appropriate Associate Editor. Two members of SPRU will be asked to provide a short written review within three weeks. The revised versions of the paper, together with a reply to the reviewers, should be sent to the Associate Editor, who will propose to the Editors its publication on the series. When submitting the authors should indicate if the paper has already undergone peerreviewing, in which case the Associate Editors may decide to skip internal review process.

\section{Website}

SWPS: www.sussex.ac.uk/spru/research/swps

IDEAS: ideas.repec.org/s/sru/ssewps.html 


\title{
Innovation as Growth Policy: the challenge for Europe ${ }^{1}$
}

\author{
Mariana Mazzucato \\ SPRU, University of Sussex, UK \\ Carlota Perez \\ London School of Economics, Nurkse Institute, Estonia, \\ and SPRU, University of Sussex, UK
}

Version: July 10, 2014

\begin{abstract}
To be published as chapter 8 in Fagerberg, J., S. Laestadius and B. Martin (eds.) The Triple Challenge: Europe in a New Age (Oxford University Press)
\end{abstract}

\begin{abstract}
The advanced world is facing a crucial moment of transition. We argue that a successful outcome requires bringing innovation to the centre of government thinking and action and that, in order to do this, we must apply our knowledge of how innovation occurs and how to repair what has gone wrong. We look first at the role that innovation has always played as the driver of economic growth, and at its relationship with finance. Arguing that the challenge today is not to 'fix' finance while leaving the economy sick, but rather to change the way that the real economy works, we then identify the solution: a policy direction that is smart, inclusive and takes advantage of 'green' as the next big technological and market opportunity. We then explain why the role of the State is key to ensuring that such opportunities are taken, and the importance of direct public investment for promoting the creation of public goods and courageous risk-taking in research and innovation in both the public and private sectors. Paying particular attention to Europe, we then examine the potential of such innovation-oriented policies to promote inclusive growth. We consider concrete steps that could be taken, both at the national and EU levels, to create the 'smart governance' necessary to implement such a direction. The chapter closes with suggestions for policies that aim to construct collective competitiveness across the European Union
\end{abstract}

Keywords: Growth policy, innovation, green growth, inclusive growth, technological revolutions, role of government, mission-oriented investments, value creation, definancialisation, respecialisation

\footnotetext{
${ }^{1}$ The authors wish to thank Tamsin Murray-Leach for editorial assistance on this chapter and Caetano Penna and the book editors for their useful comments. The usual disclaimers apply. Mazzucato acknowledges support from INET grant 1200037.
} 


\section{Table of contents}

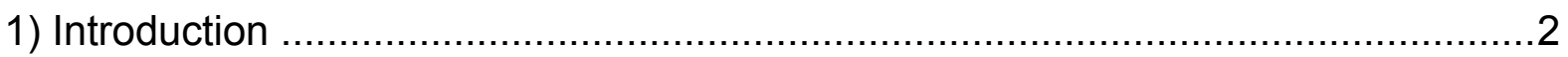

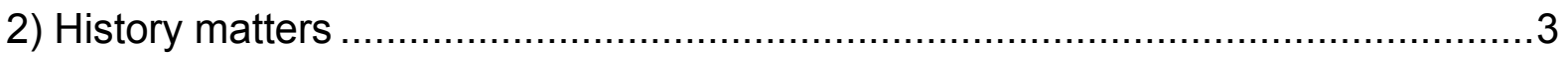

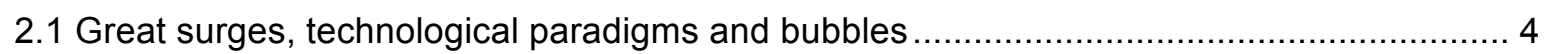

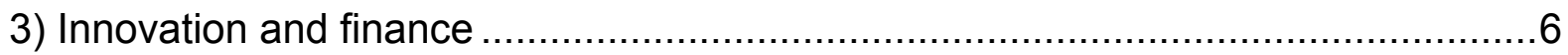

3.1 Uncertain cumulative innovation requires patient, long-term, committed capital ............... 7

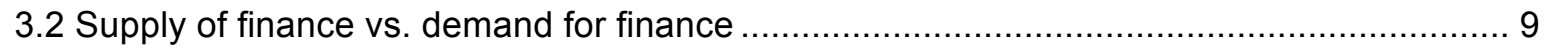

4) The Green direction ...................................................................... 10

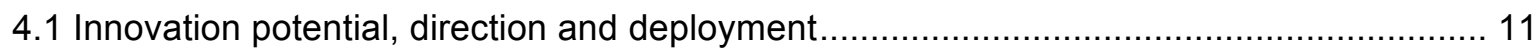

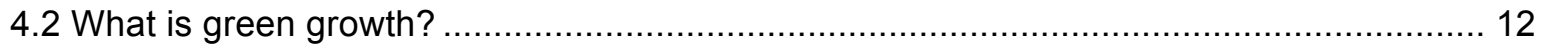

4.3 A political choice for growth, convergence and synergies .......................................... 13

5) State as lead market-creating 'investors', not market-fixing 'spenders' ...............14

5.1 Investment for innovation and competitiveness in the Eurozone .................................... 16

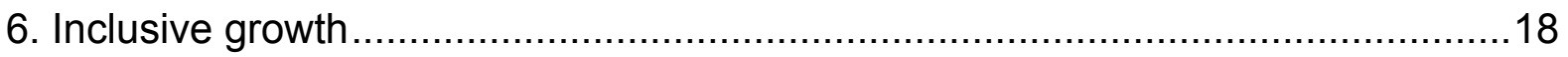

6.1 Unemployment and the need for respecialisation ....................................................... 18

7) Smart innovation requires smart government …….....................................20

8) Conclusion - Towards a new European competitiveness .................................21 


\section{1) Introduction}

The advanced world is facing a crucial moment of transition. The 2008 bubble collapse left behind it the polarisation of incomes, high unemployment, low growth and a fearful financial sector that is steering away from funding the real economy and stays in a casino world, harming the prospects of revival. Indeed, the current emphasis on 'fixing finance', while leaving the real economy sick, risks setting the stage for the next bubble.

In this chapter, we argue that the theories underlying current policies are misguided and that the aim of returning to 'business as usual' is therefore mired in a fundamental misunderstanding. Current problems are structural and date back to decades before the crisis began. In particular, we take issue with the prevailing beliefs about private and public investment and about the role of the State in such investment. We also provide a different narrative of the State, in which what is needed is not just counter-cyclical spending, but an investment-driven, 'mission-oriented' (Foray et al., 2012) and courageous State that can not only guide Europe out of the crisis but also steer and direct growth when it returns (Mazzucato, 2013a). As increasing numbers of policy makers are recognising, dogged subscription to orthodoxy is a dead end: markets alone cannot return us to prosperity. Our work has shown that investment is driven by innovation; specifically by the perception of where new technological opportunities lie (Pavitt, 1984; Perez, 2002). Private investment only kicks in when those opportunities are clear; public investment must be directed towards creating those opportunities across all policy spaces and affecting the entire economy. Furthermore, the State's role as an investor involves taking risks: win some, lose some. Such risks must be rewarded so that taxpayers not only socialise the risks, but also share in the rewards (Lazonick and Mazzucato, 2013).

We hold that success in the current transition requires bringing innovation to the centre of government thinking and action. Innovation policy must become growth policy and vice versa. In doing so, innovation-growth policy will affect all other policies: financial market reform, labour market policy and especially taxation. A clear understanding of the innovation potential inherent in the current historical moment will inform the direction that such policies take. Naturally, different pathways can be chosen while moving in this direction, but recognising the role of policy in choosing it enables a better understanding of the 'boundaries' within which civil society and other forces can operate (Stirling, 2009).

This chapter focuses on applying our knowledge of the ways in which innovation occurs (clustered and wave-like; collective; uncertain; and cumulative ${ }^{2}$ ) in order to understand what must be done to generate long run growth which is both 'smart' and 'inclusive'. It fundamentally seeks to both understand what has gone wrong and how to repair those failings. We will first look at the role that innovation has played as the driver of economic growth since the start of the Industrial Revolution, using the long-term lens of technological regimes and paradigms (Dosi, 1988; Perez, 2002, 2010) to characterise the current transition period in its historical context. These insights enable us to

\footnotetext{
2 This brief definition draws on histories of innovation studies that have emphasised these characteristics, such as Dosi and Nelson (1994), Freeman (1994), and Lazonick (2009).
} 
understand that the challenge today is not to 'fix' finance while leaving the economy sick, but rather to change the way that the real economy works. This change must include de-financialising the economy and redirecting investments towards productive mission-oriented areas.

We argue that the way to get the real economy to operate in the current context is to employ a policy direction that is smart, inclusive and green. 'Green growth' can become the next big technological and market opportunity, stimulating and leading private and public investment. This brings us to a discussion on the role that the government plays in ensuring that such opportunities exist, and particularly the importance of being able to invest - welcoming the underlying risk and uncertainty - along the entire innovation chain, not only in areas characterised by positive externalities (such as research and development (R\&D). We then offer some criteria for specific fiscal/tax policies in order to achieve such a reorientation (making it more profitable for productive investments and less profitable for speculative ones), and for creating the 'smart' governance necessary to implement such policies. Without smart government at the organisational level, smart (innovation-led) growth is impossible. We look at the effect that such policies have on steering missions and promoting more inclusive growth, where the State not only socialises risks but also rewards. We argue that such policies are themselves innovation policies and conclude by summarising eight key criteria that we believe can help growth policy be guided by long-run value creation.

\section{2) History matters}

It is not enough to agree, as many economists do, that innovation is a key driver of economic growth. In order for this assertion to have real meaning and to produce coherent recommendations across policy arenas, the underlying assumptions of the models and frameworks that guide the policies must be connected with a deep understanding of how innovation actually comes about. Here, a major strength of the Schumpeterian evolutionary theoretical framework is the significant attention it has placed in recent decades on understanding the 'process' of innovation (Freeman, 1994).

Contrary to other investment decisions (such as those relating to stocks, bonds or business expansion), which entail a calculable economic risk, innovation is a non-probabilistic process with 'odds' of success or failure that cannot be calculated in advance (Knight, 1921). Furthermore, innovation is not a 'random' variable (that is, independently and identically distributed) but is instead subject to clustering in systems (Freeman and Perez, 1988; Schumpeter, 1912). Indeed, it tends to be cumulative and path-dependent, with innovation today building on yesterday's innovation (David, 2004; Dosi, 2005; Lazonick, 2011). This is very different from the view in new growth theory (Romer, 1994), where innovation is seen as risky (as opposed to uncertain) and R\&D can be modelled as a lottery and be random in its outcomes (with little possibility of fat tails and clustering). 
In this context, it is crucial to understand the deep sense in which Schumpeter saw innovation as the driver of growth in capitalism. While he claimed that bankers are at the heart of capitalism and that credit creation is what brings expansion (Schumpeter, 1934 [1912]), he was clear that this was as a response to innovation opportunities. In Schumpeter's view, it is not the availability of money that leads to innovation, investment and growth; it is the availability of potential innovations, as investment opportunities, that brings forth the money (Schumpeter, 1939). Without such opportunities, no amount of tax breaks, quantitative easing or toxic debt will expand the real economy.

Indeed, Pavitt's (1984) taxonomy of innovation places technological opportunities (along with conditions of appropriability and knowledge base) as a key driver of investment. This is related to a key finding in industry dynamics that entry rates in new sectors are un-correlated with current rates of profits; it is the perception of future profits and growth rates that drives entry (Dosi and Lovallo, 2007). Indeed, this is what Keynes meant by 'animal spirits' (Keynes, 1936). As opposed to shortterm casino-type speculation, production investment is driven by a gut instinct about future technological and market opportunities, not the current bottom line. Therefore, the question for policy makers should not be how to make it easier for businesses to invest, but how to stimulate their courage and desire to do so. As discussed in Mazzucato (2013a), we are not faced with a lion in a cage that needs to be released by taking away the impediments (tax and regulation); rather, we must first turn the pussycat into a lion. Indeed, Keynes' assertion that businessmen were not lions, tigers or wolves, but domesticated animals (Keynes, $1938^{3}$ ) poses a very different policy agenda, even for Keynesians. While counter-cyclical spending is an important part of the solution, it also involves moving the boom in the right direction, with businesses willing and able to spend in the uncertain technological areas that could be the key drivers of growth in the future.

\subsection{Great surges, technological paradigms and bubbles}

To understand how to drive public and private investment around mission-led innovations, it is first necessary to understand similar challenges in previous crisis periods. The current emphasis on 'financialisation' - that is, too much speculative investment and not enough productive investment makes speculation and short-termism appear unprecedented (Haldane, 2011). However, this view is theoretically short-sighted because it discards the possibility of learning from history and understanding why, for example, we are now in a period that is more similar to the 1930s than to the 1980s. Applying insights from Perez's (2002) work on technological paradigm shifts, bubbles and great surges of development enables us to grasp the specificities of each historical period of development and how the patterns observed in each of those periods are replicated today.

\footnotetext{
3 'Businessmen have a different set of delusions from politicians, and need, therefore, different handling. They are, however, much milder than politicians, at the same time allured and terrified by the glare of publicity, easily persuaded to be "patriots", perplexed, bemused, indeed terrified, yet only too anxious to take a cheerful view, vain perhaps but very unsure of themselves, pathetically responsive to a kind word. You could do anything you liked with them, if you would treat them (even the big ones), not as wolves or tigers, but as domestic animals by nature, even though they have been badly brought up and not trained as you would wish....' John M. Keynes's private letter to Franklin D. Roosevelt, 1 February, 1938.
} 
The crash of 1929 ended the prosperity bubble of the roaring twenties in the USA, just as the NASDAQ crash in 2000 and the collapse of 2007-08 ended the bubble booms of the 1990s and 2000s, respectively. The 1920s had seen the emergence of the automobile, universal electricity, petrochemicals, radio and the mass production paradigm (Freeman and Perez, 1988). The 1990s and 2000s witnessed the explosion of information and communications technologies (ICT), the spread of flexible production systems (Womack et al., 1990) and the installation of the global Internet and its consequences on globalised finance, trade and production (Boyer, 2000). Both of those real investment booms turned into 'casino capitalism' (Perez, 2002). In each case, there was a significant shift in the rankings of industries and countries; in each, the bust led to a freezing of 'animal spirits' and revealed the decoupling of the financial world from the real economy (Krippner, 2005; Dore, 2008) and also caused growing income polarisation. On both occasions, a huge innovation potential was installed and ready to flourish but, then as now, 'financialisation' and resistance to government action stood in the way.

It is this understanding that points to a parallel between today's crisis and opportunities and those of the 1930s rather than with the 1980s. The call for unfettered free markets in the 1980s assumed that the cause of the recession was government regulation (Derthick and Quirk, 1985). However, when viewed with an understanding of the pattern of technological revolutions, the stagflation of the 1980s was not caused by excess government but by a lack of innovation potential. It was the exhaustion of the mass production trajectories that drove the post-war boom, while the ICT revolution was only just emerging- albeit with great speed and great promise, but without enough weight to drive the whole economy out of decline (Perez, 2002). The pro-market policies enabled the survival of companies with mature technologies. With less regulation, these companies were able to close down facilities, move offshore, reduce personnel, pay lower wages and taxes, and regain profitability through cost-cutting (O'Sullivan and Lazonick, 2000). Higher productivity did not occur then due to increasing returns to scale, as would have been expected by the Verdoorn effect (Verdoorn, 1949; Kaldor, 1966), but rather due to the radical elimination of less productive facilities and many jobs, applying what Freeman and Soete (1994) called the 'Verdun effect'. ${ }^{4}$

By contrast, the government strategy around microelectronics, and the computer revolution itself, was very active (Block and Keller, 2011) and created increasing opportunities for new entrants. Funding for small businesses through the SBIR programme in the United States (such as Compaq, Intel and Hewlett Packard), public procurement for high-tech companies, and R\&D funding for universities and government labs all provided the groundwork for the key technologies that would lead to the PC revolution and later to the Internet revolution.

Thus, the bubble boom of the 1990s was not the result of less government but instead the explosion of the ICT revolution riding on government-funded technologies ranging from integrated circuits to the Internet (Block and Keller, 2011; Lazonick and Tulum, 2012; Mazzucato, 2013a). Equally, the

\footnotetext{
${ }^{4}$ A pun, referring to the destruction of the French positions in Verdun by heavy German artillery, during the First World War.
} 
global boom of the 2000s was enabled by governments (national and foreign) providing masses of funds and easy credit. Where governments did fail to provide adequate regulation was in the financial sector, with the unfettered proliferation of toxic financial instruments having catastrophic consequences (Perez, 2009). Today, as in the 1930s, both economists and politicians are increasingly concerned with the reluctance of finance to fund the real economy. As Keynes (1930:1931) wrote in 'The Grand Slump of 1930':

.... there cannot be a real recovery, in my judgment, until the idea of lenders and the idea of productive borrowers are brought together again... Seldom in modern history has the gap between the two been so wide and so difficult to bridge.'

We now turn to the relationship between finance and innovation.

\section{3) Innovation and finance}

Today, as in the West in the 1930s, governments across the world are trying to 'rebalance' the economy away from speculative finance and towards productive finance that can nurture growth in the real economy. Figure 1 below shows the problem, especially in countries like the United Kingdom and the US, where finance outgrew the real economy for years, leading to the crisis (Krippner, 2005; Dore, 2008). Financialisation has been caused by two factors. The first is the financial sector mainly lending to itself rather than to the real (production) economy, ${ }^{5}$ with the risks being far higher but severely under-priced. The second factor is the corporate sector's concentration on short-term boost to profitability (through mergers and acquisitions (M\&A) activity and divestiture from long-run areas like R\&D), and boosting stock prices and stock options (hence executive pay) through the increased trend of share buybacks (in the last decade, these have exploded to $\$ 3$ trillion for the Fortune 500 companies alone (Lazonick and Mazzucato, 2013).

The former factor resulted in bank assets ballooning, but these assets were increasingly fictitious. When asset prices fell and bank equity was wiped out, banks were so highly leveraged that it required only a 3 percent fall for the major bust to occur. Before that happened, however, bank assets and profits expanded relative to the rest of economy, increasing their value-added contributions, as this is measured indirectly by their interest margin (see Figure 1 for the UK). The latter has caused company profits to be reinvested in speculative areas and also led to record levels of hoarding, reducing the endogenous creation of new opportunities for future growth: human capital and R\&D.

\footnotetext{
${ }^{5}$ By real economy, we mean growth of production in both manufacturing and services that leads to job creation. It is common to distinguish the growth of 'real' value added from value added in finance and agriculture.
} 
Fig. 1 Financial intermediation as a percentage of gross value added; UK 1945-2013.

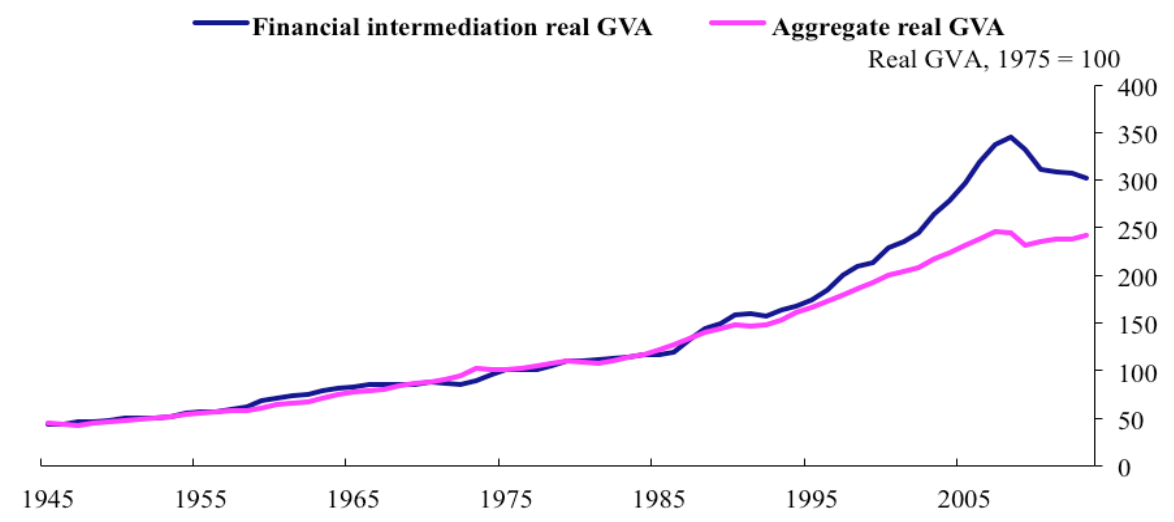

Source: Alessandri and Haldane, 2009 (2009-2013 data extended by authors with data from the Bank of England).

In this context, finance is not playing the role of the 'ephor' of capitalism (Schumpeter, 1934 [1912], p.74), and business is not displaying the investment behaviour that Keynes wished for. Instead, the traditional banks and even the venture capitalists have become increasingly risk-averse. Venture capital is focused on the exit, within three years, usually via an initial public offering (IPO) (Lazonick and Tulum, 2011). However, major innovations can take 15-20 years to fully develop, which means that this particular financing model only works for gadgets that ride on existing technology, rather than the big waves of the future. Thus, secular stagnation is a result of this financialisation, not an excuse for it. Indeed, while a common excuse for buybacks is that they are used when there are no opportunities for investment, ${ }^{6}$ Figure 1 shows that they are actually causing the dismantling of future opportunities, not reacting to lack thereof. Technological and market opportunities have always been a function of the private and public sectors interacting in dynamic ways. Indeed, a recent MIT report shows that the real problem is the lack of an engaged private sector, with the current absence of large R\&D laboratories at private companies, such as those like Xerox Parc and Bell Labs that co-invested alongside the State in the 1960s (MIT, 2013).

Given the short-termist financial sector and the financialised real economy, policies based on the false assumption of the existence of a shortage of finance are doomed to failure. In order to understand why it is not the quantity of finance but the quality that is important, it is necessary to first look more closely at the relationship between finance and innovation.

\subsection{Uncertain cumulative innovation requires patient, long-term, committed capital}

Innovation and finance affect each other. Different kinds of companies and industries, depending on their stage of evolution, require different types of finance, but the finance they actually receive affects their investment patterns and company characteristics (Mazzucato, 2013b; O'Sullivan, 2005). Those companies that want to invest in truly radical new technologies or in sectors in which innovation has a long lead-time (such as pharmaceuticals) require finance that is patient and long-

\footnotetext{
${ }^{6}$ Of course, what they mean by 'no opportunities' is no-easy-three-year-high-return opportunities that can yield as much as financial gains. It is this distorted market situation that needs to be put right by policy action.
} 
term in nature. Also, because innovation is cumulative, finance must always be 'committed'. Across the globe, this long-term funding has often come about through public institutions, whether they are public agencies like DARPA (the Defense Advanced Research Project Agency) in the USA, or through state investment banks like the German KfW or the Chinese Development Bank (Block and Keller, 2012; Mazzucato, 2013a; Mazzucato and Penna, 2014). Indeed, 'mission-oriented' public sector investments have been fundamental in creating the new opportunities that later drive the private sector to enter new sectors and invest in new technologies (Mowery, 2010).

Understanding the feedback relationship between innovation and the 'type' of finance also helps us understand the relationship between technology and bubbles (Perez, 2002, 2009; O'Sullivan, 2005). Periods during which low-cost finance is widely available but there are few profitable opportunities in the real economy will result in unproductive paper bubbles. Bubbles may still result when finance is chasing real technological opportunities, but the infrastructural remnants (new railroads, new electrical networks, new Internet technology) will continue to fuel growth for decades. What the government provided in the 1990s boom was not easy money but new opportunities in the form of new technology (the Internet) that was a powerful platform for innovation - indeed, a 'general purpose technology' (Lipsey et al., 2005). The high real interest rates prevalent at that time in the US (approximately 7 percent) were the same as they were during the stagflation of the 1980s, yet this did not deter investors who recognised the above-mentioned opportunities (Figure 2A).

Figure 2: Without technological opportunities, easy money leads to casino finance.

(A) US real interest rates 1993-2008

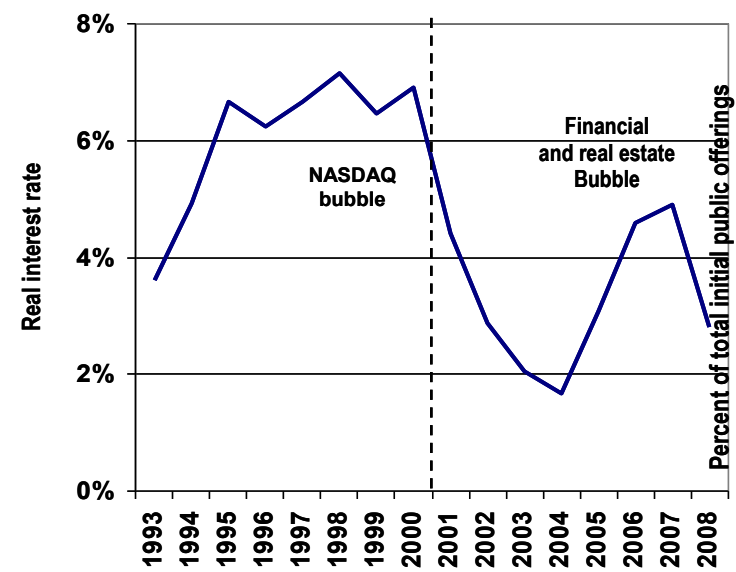

Source: Data from World Development Indicators
(B) ICT and finance IPOs as percent of total in US stock markets 1993-2007

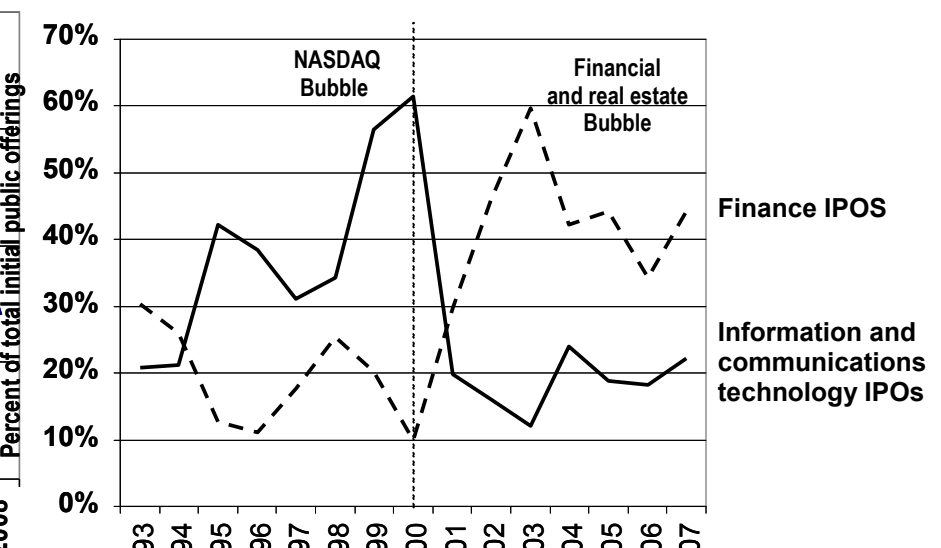

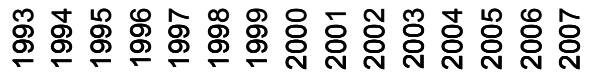

Source: Data from Thomson

During the dot com bubble, however illusory the promised gains turned out to be, they looked like real opportunities. Therefore, the high cost of credit was no deterrent; at the peak of the bubble, 60 percent of the IPOs in the US stock markets were in ICT stocks (Figure 2B). The fact that real technological opportunities underlay the over-investment meant that even though a (dot-com) bubble followed, it still left behind a worldwide telecommunications network that facilitated globalisation and a social learning process around the web that enabled the innovations that emerged in social networks and mobile telephony. By contrast, the much lower interest rates 
(between 2 and 5 percent) that prevailed in the 2000s (Figure 2A) led to the development of new financial instruments for reaping capital gains without having to invest in new (now 'risky') technologies. During that period, easy credit inflated the housing bubbles, while the (much reduced) flow of investment to the stock market involved twice as many finance IPOs as ICT ones.

There is no reason to expect that zero interest rates will bring a better outcome now. Indeed, the results of the recent bouts of worldwide money printing, euphemistically referred to as quantitative easing, have been meagre and have mainly leaked to the emerging markets. This again shows that the revival of real investment does not depend mainly on the amount of finance available or on its low cost, but on the way it is introduced into the economy. Only by directing the creation of money (for example, by co-financing European Central Bank (ECB) bonds with European Investment Bank (EIB) bonds and guiding the former towards productive investments all over Europe) will the stimulus lead to long-run growth rather than short-run blips.

\subsection{Supply of finance vs. demand for finance}

The assumption that there is a finance shortage in both the public and private sides is not only untrue but also leads to incorrect policies. Today, capital is not scarce (Christensen and van Bever, 2014 ) - almost $\$ 1.2$ trillion is being hoarded in the private sector in the US and close to $\$ 0.7$ trillion in Europe (Zenghelis, 2011) - it is just the wrong type of finance.

A related false assumption, among both mainstream and some heterodox economists, is that there is a 'financing gap'; that is, a credit crunch that requires policy to induce the banks to lend. In reality, with regard to important innovation, there is as much of a demand-for-finance problem as there is a supply-of-finance problem. By insufficient demand, we mean that there are not enough courageous firms that see clear profit opportunities and are willing to make long-run commitments to high growth areas that require major innovations (NESTA, 2009; Storey, 1994). It is that sort of demand that can drive the revival of growth and employment. This cannot be achieved by pushing the banks to lend or by making life easier for businesses through various types of tax reductions and tax credits.

The question, then, is not how to provide easy money, but how to bring forth the opportunities, how to mobilise the supply of innovation, how to activate entrepreneurship both public and private. The opportunities will bring forth the money. The emphasis on commercialisation assumes that all that is needed is intermediary institutions, and that the quality and quantity of the science base is not a problem. In reality, there has been a massive underinvestment across Europe in key science areas, leading to knowledge transfer policies 'pushing on a string' (Dosi, Llerena, and Labini, 2006).

It is not sufficient to simply recognise the importance of innovation; it is these accompanying assumptions that matter. The differences in how we understand innovation (path-dependent and cumulative vs. a random variable), uncertainty, and the characteristics of investment (driven by the perception of future technological opportunities vs. driven by easy and cheap money) will determine the details of innovation policies and, most importantly, our growth policies. 
Returning to the 1930s, we see that both Keynes and Roosevelt, coming from completely different angles, not only tried to make investors pull their money out of the banks and bring it into production, but also saw the State as the only entity capable of mobilising the economy. They argued that this should be done not by giving money to the banks, but by 'pulling' investment and innovation, either through government investment and procurement and/or by putting money into the hands of those with a high propensity to consume. Following Keynes and Roosevelt, such dynamic sources of reliable demand would create the necessary inducement for idle money to invest in production and revive the economy. Innovation was not in their vocabulary, nor in their explicit thoughts; yet the nature of the innovation potential that had been installed during the 1910s and 1920 s was inherent to their plans. What made growth actually happen, however, was having a direction for its deployment.

\section{4) The Green direction}

It is important to emphasise the distinction between a technological revolution, the potential inherent in that revolution, and the direction of investment and innovation in which that potential is deployed (Perez, 2013a and b). Technological revolutions, such as those that brought the railway age in the $19^{\text {th }}$ century, the age of mass production in the early $20^{\text {th }}$ century and the information age now, are based on an interrelated set of new technologies, industries and infrastructural networks that develop in intense feedback, providing markets and suppliers for each other (in the way that computers generated markets for micro-chips and the Internet generated markets for computers, and so on). In the process, these revolutions also provide a new potential to transform and enable innovations in all other industries. We now have smart grids, cars and soon houses, with the 'Internet of things'; nanotech and biotech are completely ICT-enabled and can, in turn, help innovate in other industries. Even the globalisation of production and trade has been made possible by the Internet. However, that potential does not have the same self-propelled nature as ICT itself. Its possibilities are disparate and often unconnected; it can be used and shaped in different ways and profitability depends on relative costs and especially dynamic demand. Only a common direction can contribute such synergies. Thus, in contrast with the revolutionary industries, the direction chosen for using the new potential across the economy becomes a socio-political choice. ${ }^{7}$ The direction provides convergent trajectories for the multiple and disparate industries to innovate, while generating common synergies (suppliers, skills, equipment, service and distribution networks, demand patterns, etc.) that provide advantages for all participants (Perez, 2013b). Suburbanisation and the Cold War played that role in the post-war boom in the West; today, 'Green Growth' can serve as a powerful global direction for deploying the potential of the information revolution. If it is widely understood, such a socio-political choice can reorient innovation across the entire economy, providing a variety of energy sources, a major increase in the productivity of natural resources, and new sustainable lifestyles and patterns of production (Perez, 2013b). It would also enable full global development, given that the continuation of the American way of life for the billions of new

\footnotetext{
${ }^{7}$ Hitler, Stalin and the Western democracies made profoundly different choices for innovation with mass production across the economies involved.
} 
consumers entering the market in the emerging and developing worlds would soon reach planetary limits (Rockström et al., 2009) if it were not reshaped for sustainability.

\subsection{Innovation potential, direction and deployment}

The effect of a green direction would be the equivalent of the effect that suburbanisation and the energy-intensive and materials-intensive lifestyles had on the potential of the mass production revolution after the war. Such successful deployment periods result from purposeful strategic policies. When Keynes said it was fine to simply 'dig ditches and fill them up again', he was desperately trying to put income in the hands of consumers: enabling mass consumption to entice mass production. The specific conditions of his time allowed him to ignore the great importance of the 'direction' of stimulus spending. Yet, the Second World War inadvertently provided this direction by creating massive demand for military innovation and for deploying the mass production of equipment. Having learned that lesson, reluctant businesses (and many equally unwilling politicians) finally accepted State involvement in the economy. Bretton Woods and the Welfare State stabilised international trade and established a reliable expectation of increased disposable income across the national population for the spread of the successive innovations of the American way of life.

To understand the importance of giving a direction to the potential, we must delve again into the neo-Schumpeterian understanding of innovation. Products are not developed in isolation but in technology systems (Freeman, 2008) where each innovation creates problems that call forth solutions from suppliers (Rosenberg, 1983), which spur investments and can lead to entire new industries. Universal low-cost electricity brought mass use of refrigerators and freezers, which spawned innovations in frozen foods, which created the need for innovations in packaging methods and materials. This clustering of interdependent users and producers and of self-reinforcing capabilities results in synergies and support networks that make further innovations easier and profitable (that is, they involve less uncertainty) (Lundvall et al., 2002). At the same time, the aims of 'disposability' and 'reducing work in the home' converged to become common guidelines for innovation trajectories across many industries during the post-war boom. Multiple plastic materials were developed so that dishes and bottles did not have to be washed or returned; synthetic fibres were designed to allow no-iron garments and plastic disposable packaging was made available for processed, refrigerated and frozen foods. This encouraged the production of special equipment and the training of personnel for shaping, casting, extruding and otherwise making it easy to innovate using plastics, which increased the markets and reduced the cost through economies of scale. This made it even easier to replace natural materials with synthetic ones when making electrical appliances for kitchen and entertainment. However, without the Welfare State and official labour unions, which made home ownership and instalment buying a reality for the great majorities, the mass demand would not have been there to generate the scale and the synergies that made it all possible.

Indeed, suburbanisation - based on cheap houses built on cheap land, full of electrical appliances and with a car at the door - was not only stimulated with roads and other means but often publicly 
guaranteed (as was the early case of the Federal National Mortgage Association (Fannie Mae) in the US in 1938). The installed technological potential then benefitted from cheap energy and from standardised consumption patterns, enabling economies of scale to be exploited. This lifestyle shift was aided by labour unions keeping salaries apace with productivity increases, shorter working hours, unemployment insurance and pensions. This social security framework, strengthened by the personal credit system, facilitated a steady increase in per-household consumption that brought forth successive series of inter-related innovations spreading across individual domestic markets and overflowing into the rest of the world. In Europe, which had a stronger social democratic tradition, even bolder innovations were spurred by government funding and procurement in national health systems, education and other public services. Depending on the specific context of each advanced country, there was a varying degree of expenditure in the two aspects of the Cold War - the arms race and the provision of social welfare and good living for the majority of people - both of which contributed to innovation and market expansion.

In essence, the huge innovation potential of the mass production revolution, which had been installed by the 1930s, was only expressed in growth and prosperity when the government provided a direction for its deployment, together with the institutions that sustained it. This is why it is so important to move away from a view of the State simply providing a fix to a market failure to one that makes and stimulates investments and mission-oriented innovations (Mowery, 2010). When one asks what missions could drive investment today, and what direction can be given to the full deployment of the ICT industries and to their capacity to transform all other activities, the answers are very different answers from those arising from doomsday scenarios that see a lack of technological potential, and therefore no substantial opportunities for growth (Gordon, 2012), or the over-optimistic scenarios that rely on technology and markets to do the job (Brynjolfsson and McAffee, 2011) with a few educational nudges from the State and in the current - financialised conditions.

\subsection{What is green growth?}

Green growth is more than just low-carbon and renewable energies. From a technological point of view, renewables alone do not constitute a synergistic technology system. There is not enough technological convergence in knowledge, suppliers, engineering or skills between solar, wind, wave, geothermal or hydroelectric energy equipment. In order to benefit from all the potential synergies, the environmental challenge must be seen with a wider lens. Apart from the technologies that enable flexibility and interaction in the space of renewable energy, such as batteries, smart grids and the like, the green direction would have to encompass what can be termed green growth. This would include conservation; pollution control; reduction of material content per product; designing for durability; replacing products, possession and waste with services, rental and maintenance and recycling, respectively; promoting the flourishing of the creative economy; making cities more liveable and less polluting; revamping transport systems and the built environment; promoting collaborative and sharing economies; focusing on health (including preventive and personalised 
medicine); and promoting all forms of education, in and out of schools. This type of growth implies a redefinition of the optimal production practices and a different view of the 'good life', shaping the desires and aspirations of the majority. In other words, green growth involves a gradual transformation of the entire economy, reversing the mass production and consumption patterns of the previous revolution and making it cost-effective and profitable to introduce a wide range of innovative changes in production and lifestyles that would increase sustainability and reduce carbon, while improving the quality of life for all.

\subsection{A political choice for growth, convergence and synergies}

'The good news is we are sitting on a complete revolution of technology that allows us to move in a sustainable direction. That's a matter of choice though. Markets alone won't take us there. We have to decide on planetary scale, we're going for a sustainable, green, inclusive economy.' (Sachs, 2014)

Why can't markets find the green direction on their own? The reason is because there is no readymade route that will make the multiple possible directions and disparate innovations profitable. The main characteristic of innovation is uncertainty and it is only in the context of a revolution or when a direction has been clearly chosen and made reality through policy action that the risks will diminish and innovations proliferate in that space and start to create synergies for each other. There are already innumerable experiments in the private sector, not only in alternative energy, batteries, electric cars and the like but also in radically new environmentally friendly production methods, such as the circular economy (Ellen McArthur Foundation, 2012/2013) or 'cradle to cradle' (McDonough and Braungart, 2002), which aim to eliminate effluents and waste; or industrial symbiosis (Chertow, 2000; Lombardi and Laybourn, 2012), in which industries use each other's waste as inputs. There have also been significant efforts to stimulate policies in the public sector. Examples include the German, Danish and Swedish policies on renewable energies; the EU directives on recycling; and tax and other policies in various countries that aim to increase consumer purchases of zero-emission cars or installation of solar panels. ${ }^{8}$ However, all of these separate attempts are far from sufficient and evolve too slowly to yield the required growth results. Most of them are too uncertain to attract finance and too disperse to guarantee demand and generate strong synergies. It all needs an intense collective push to really take off and Europe is a large enough market to be able to make a difference if its member countries act in unison. The problem is that there is still a somewhat fundamentalist understanding of the nature of the free market as neutral and unregulated, when in fact markets would be much more dynamic and profitable if the playing field were clearly and intelligently tilted. As mentioned above, businesses were fiercely resistant to the New Deal and government intervention until they experienced the advantages of receiving State support and a clear direction during the Second World War. In the heyday of free markets in the $19^{\text {th }}$ century, the

\footnotetext{
${ }^{8}$ Indeed, Tesla cars sell so well in Norway (which buys 80 percent of them) because the Norwegian government has made it a convenient and profitable purchase: no tax is paid on purchase; no city parking permit is needed; and drivers can use taxi lanes.
} 
British Empire, with its procurement practices, served as the pacesetter for business expansion and innovation.

The complex feedback loops between government policy, business strategies and consumer preferences are unpredictable, but without clear and stable policies they may take even longer or not happen at all. What the green direction can do today, through a clear, coherent and stable set of government policies, is to tilt the playing field strongly towards sustainability. This involves governments taking on the high-risk R\&D investments to unleash the truly new systems, and setting up policies so that demand, taxes, regulation, prices, procurement and all other contextual elements favour attaining profitability by increasing the productivity of resources. Industries and services that saw such opportunities would readily shift their strategies and innovation trajectories to apply criteria of conservation, durability, easy recycling, low-carbon and environmental preservation.

Such convergence in the direction of innovation would create more and more synergies, making it easier and easier to find suppliers and markets, and to grow and to restore employment levels. For the advanced countries, this may imply respecialising in two types of activities: those for high-quality or high-complexity demand sectors (both in equipment and consumer goods or services) that cannot be based on low-cost labour, and those for domestic quality of life that cannot be offshored. The former can aim to serve the high ends of the consumer markets and the infrastructure, equipment and engineering needs of the growing developing world. Among the latter, one can count on the greening of the built environment, the sharing and the rental economies, the preventive and personalised health care services, other activities related to quality of life, and so on.

After the 1929 crash, it took 12 years and a major war before governments finally set in place the institutional innovations that led to the wave of investment innovation and expansion and fully unleashed the potential that had been installed from the 1910s through the 1930s. The same force must be applied in today's context, giving a direction for the full deployment of ICT; this is a challenge that requires a re-examination of the prevailing consensus on the minimal role of the state.

\section{5) State as lead market-creating 'investors', not market-fixing 'spenders'}

The current fashion for keeping government out and for trusting markets to bring prosperity is a misreading of recent experience that does not stem from a deep understanding of the drivers of growth and of the central role played by technical change. Worse still, it ignores the role of the State as the driver of the real growth miracles of the past few decades: Japan, South Korea, Singapore, China and others in Asia (Wade, 1990; Amsden, 1989), and Germany and Denmark in Europe. Most of all, it misrepresents the entrepreneurial role of the public sector in driving the ICT revolution in the USA (Mazzucato, 2013a). The global boom of the 2000s was fuelled by the offshoring and outsourcing movement but not by innovation in new sectors. In most advanced countries, innovation was centred on the synthetic financial instruments that led to the housing bubbles and to the Lehman Brothers crash (Perez, 2009). Those bubbles were primarily enabled by governments 
providing easy credit after 9/11 and by the flows of Japanese and Chinese surplus to the West in order to fuel demand for their own export boom. Financial markets were able to exploit this new potential by lifting barriers and removing old regulations. However, no amount of market freedom could have made the private sector risk the huge investments that the US government made in the development and setting up of the Internet in the 1970s and 1980s, or nanotechnology in the 1990s (Block and Keller, 2011).

Mazzucato (2013a) argued that areas of the world that have indeed experienced innovation-led growth, such as Silicon Valley in the past or China today, are characterised by mission-oriented investments, with direct public spending in a wide host of different areas. For example, all of the technologies behind the iPhone were directly funded by government-led investments. Indeed, Apple has one of the lowest R\&D expenditures in the PC industry (Mazzucato, 2013a), precisely because it (ingeniously) uses mostly existing, government-funded technologies; Apple's secret has been to add the crucial element of design. The emergence of phone microchips is due to the US military and space programmes, which comprised almost the entire early market for the breakthrough technology (ibid; Ch. 5), driving the price of the initially costly chips down 50 times in only a few years, enabling numerous new applications. Cellular communication itself has its foundations in radiotelephony capabilities advanced throughout the $20^{\text {th }}$ century with support from the US military. The technologies underpinning the Internet, which put the 'smart' into smart phones, were developed and funded by the United States Defence Department's Advanced Research Projects Agency in the 1960s and 1970s. GPS was created and deployed in the 1980s-90s by the US military's NAVSTAR satellite programme, while the revolutionary multi-touch interface was first developed by University of Delaware researchers with support from NSF and CIA grants (Breakthrough Institute, 2010). Even the latest SIRI, iPhone 5's personal assistant, was initially developed with DARPA funding. The same applies in such areas as biotechnology, where private venture capital followed massive public investments that amounted to US\$31 billion in 2012 alone (Mazzucato, 2013a).

Growth occurs when a significant technological opportunity is located in a favourable context, and when high-risk, capital-intensive investments are made to kick-start the innovation 'machine'. No amount of price signals would have created the Internet, just as today a carbon tax or an emissions market would be crucial but not sufficient to get clean tech going. This is not only about the simple fact that Silicon Valley could not have appeared, grown and prospered in the old Soviet Union or in Sicily, for example. It is also about the conscious provision of a set of investments, incentives and conditions that will significantly reduce the risks and increase the potential profitability of what is now technologically feasible but highly uncertain, encouraging convergence in order to create further and further synergies. Policy cannot be limited to temporary counter-cyclical spending, applying a shallow understanding of Keynesian advice. In The End of Laissez Faire (1926), Keynes defined the role of government intervention in very direct terms: 'The important thing for Government is not to do things which individuals are doing already, and to do them a little better or a little worse; but to do those things which at present are not done at all.' Many companies, both large and small, are currently experimenting in the green direction, but they are far from doing it 
with sufficient scale and boldly and quickly enough to make a significant difference in growth and jobs. In order for this to be done intensively, kicks and pushes are required, not just gentle nudges, and governments must themselves take courageous risks. Generating consensus in identifying and strengthening context-specific paths in that direction (and the narrower specialisations within them) is necessary in order to revive each country's economy in the current global context.

\subsection{Investment for innovation and competitiveness in the Eurozone}

The failure to recognise the massive investments that must be made has resulted in incorrect diagnoses of weaker countries, and hence the wrong medicine. Consider the Eurozone, where the weakest (peripheral) countries are still facing problems around structural unemployment and low growth. The usual line is that the weaker countries (such as Portugal, Italy and Spain) have spent too much, but it is actually these countries that have had too little (not too much) spending in areas that create new market and technological opportunities. Figure 3 shows that the Mediterranean countries and Ireland have spent below the OECD average on gross R\&D in proportion to GDP, which is one of many proxies of how much investment is being made in shaping a dynamic future. Similar measures would be investment in human capital formation (including training programmes) and education.

Figure 3. Gross R\&D spending across the OECD

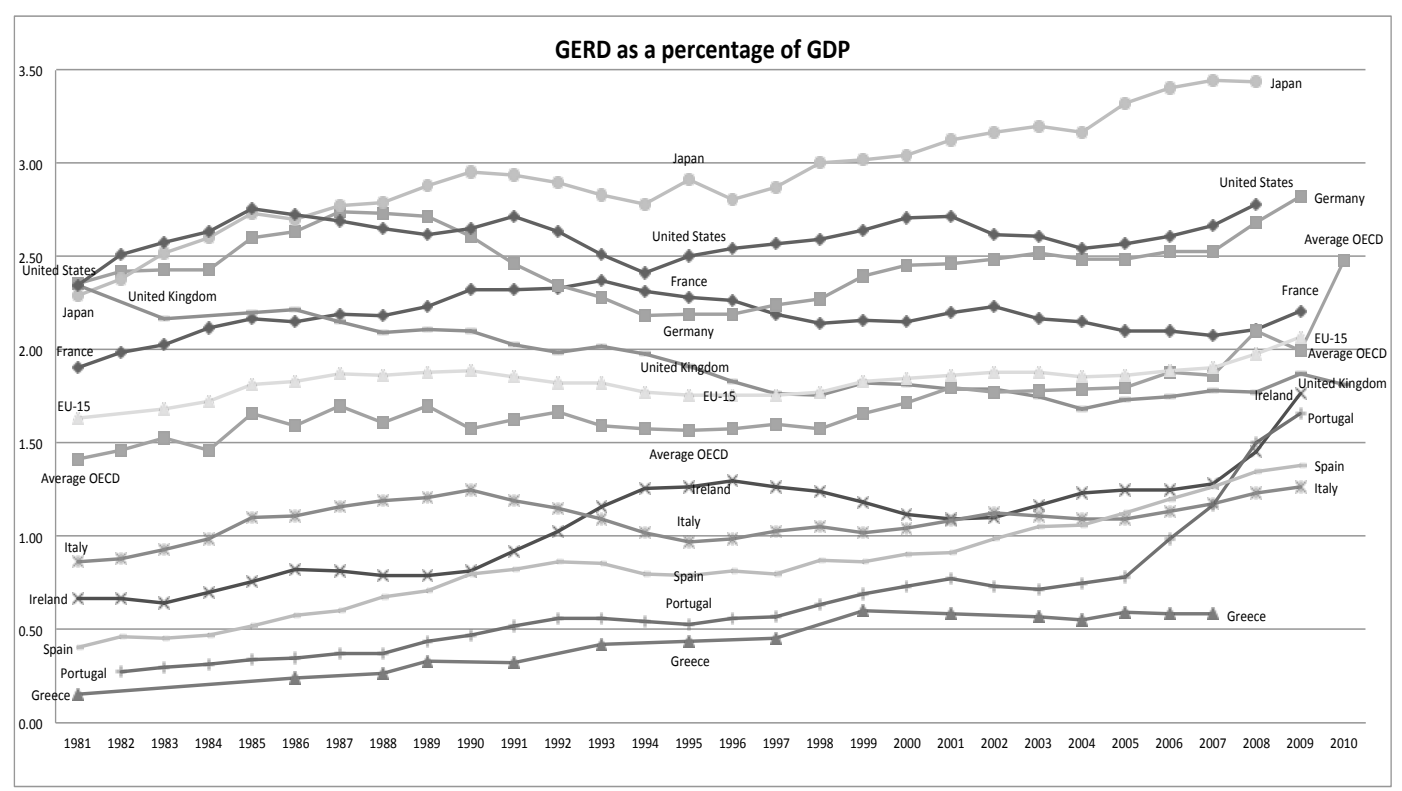

Source: OECD, 2012

Figure 4 shows that the weakest (peripheral) countries are also characterised by low business spending on R\&D (BERD) in relation to GDP. A key policy area, of course, is how to increase this figure, and there is a common belief that it can be done simply with R\&D tax credits. Such credits can help, but since spending on innovation is driven by opportunities, not costs, increasing BERD also tends to require direct public research spending in key areas that the private sector is too risk-averse to fund, but is much more willing to follow up on once the technology is ready for innovation. 
Figure 4. 2011 BERD (private R\&D spending) in relation to GDP/cap. across the OECD.

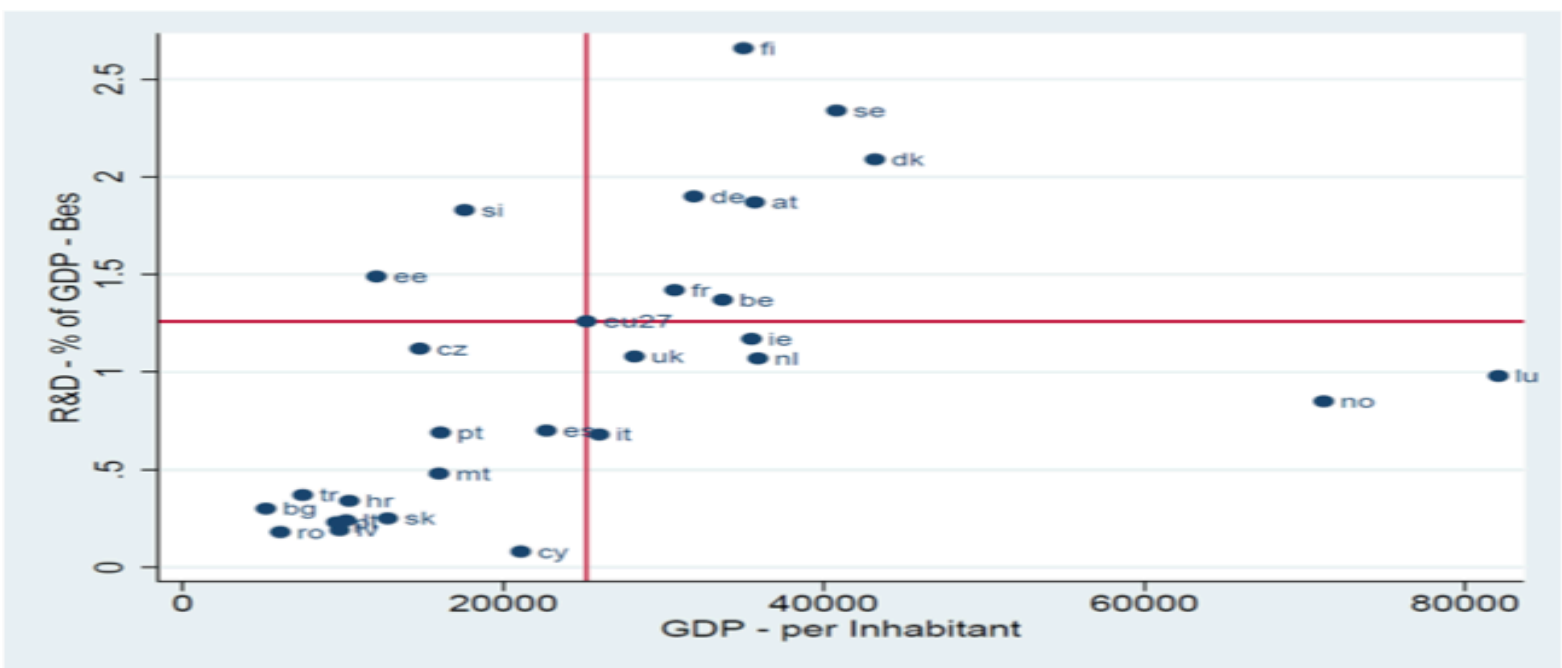

Source: OECD, 2012.

The current emphasis on Europe's problems as resulting from too much state rather than too little strategic, mission-oriented state is setting it backwards, not forwards. Across the continent, many privatisations in the 1990 s merely resulted in falling private R\&D. ${ }^{9}$

The current 3 percent deficit limit is putting a strain on economies that need to be investing, not cutting. The 'periphery' (Italy, Greece, Spain, Portugal) must spend more on areas such as education, human capital formation and R\&D. Such investments must be guided by intelligent agencies, driven by 'missions', but also facilitated through EU institutions such as the European Investment Bank, working hand in hand with the 'money creation' process of the ECB. Rather than direction-less quantitative easing, which has only increased money in the banks, not in the economy, the ECB bonds could possibly be co-financed with EIB bonds, as argued by Varoufakis, Holland and Galbraith (2013). Like the KfW in Germany, the CDB in China and BNDES in Brazil, the EIB could become a key engine for providing long-term patient capital to innovation, which is currently being impeded by short-term finance. Instead, while the EIB used counter-cyclical lending to kick-start growth from 2008-2010, it soon put the brakes on this lending due to concerns about credit ratings.

Most of the solutions put forward today are focused on structural reforms and different types of austerity; without strategic public and private investment, however, there will be no growth. As many of the structural reforms also imply cuts to public services and public sector wages, they are likely to further weaken demand and the social fabric of countries; this will reduce their ability to get out of their current situation and make them less resilient to future crises.

\footnotetext{
${ }^{9}$ An example is Telecom Italia. Unless the upcoming privatization of Finmeccanica (Italy's leading microelectronics company) is accompanied by an investment strategy, it will probably experience falling R\&D too.
} 


\section{Inclusive growth}

Rising inequality, together with unemployment, are key elements of this disintegration and can be seen as both a cause and an effect of the recent financial crisis in both developed and developing countries. However, national and transnational ambitions to generate growth that is both smart and inclusive (see, e.g., EC, 2020) are not working. This is not only due to vested interests but also to the lack of a theoretical framework in economics that will allow the connection to be posited strongly. While it used to be that economists who studied innovation also studied the distributional impacts (consider the studies of the Classical economists on the effect of mechanisation on profits and wages, as in Ricardo, 1817), there has been a sharp divide over the last century, with economists interested in innovation focusing on technology, learning, and the dynamics of capabilities. This has left issues of distribution and inequality to be studied by labour economists, mostly within a traditional neoclassical approach. In turn, governments have also divided innovation policy, labour policy and economic policy into three distinct worlds with different thinking (and no communication among them).

In recent years, there has been a return to thinking about the relationship between innovation and inequality, through new growth theory, which focuses on 'skill-biased technical change' (SBTC) (Acemoglu, 2002). Apart from methodological concerns with this method (such as the underlying assumption about how labour markets work), a key issue is SBTCs inability to explain the most dramatic increase in inequality between the top 1 percent or top 0.1 percent and the bottom income groups. In the USA, real incomes for the bottom 90 percent of earners rose only about 4 percent from 2000 to 2007, compared around 94 percent for the top 0.1 percent (Piketty and Saez, 2010; Piketty, 2014). Although it is more complex to measure comparable data across the European Union, the indices that have attempted to do this reveal that, similarly, the 'top deciles capture an increasing part of the income generated in the economy, while the poorest $10 \%$ are losing ground' (Fredriksen, 2012; cf. European Commission, 2011). Is it realistic to explain these extremes in terms of skills? We argue that it is not, and that there is a much deeper relationship between the character of innovation and its consequences on the workforce and on income distribution.

\subsection{Unemployment and the need for respecialisation}

One of the causes of major job loss or displacement is the fact that technical change occurs in clusters corresponding to successive technological revolutions. As the main industries approach maturity and exhaust their ability to increase innovation, productivity or markets, they must shed labour, close down facilities, migrate in search of lower costs and new markets or disappear (Freeman and Perez, 1988). The modernisation option, using the emerging technologies and infrastructures of the next technological revolution, will imply radical skill changes, but only appears years later. That was the case with the application of mass production techniques in the early $20^{\text {th }}$ century, and more recently with flexible production and the globalisation of value chains brought about by the ICT revolution (Van Ark, 2001). These processes are at the root of the changing production landscape, with some regions declining as others flourish, and some skills being devalued 
(or jobs disappearing) as others gain in value and as new activities find entrepreneurial use for the displaced workers (Brynjolfsson and McAffee, 2011). Understanding the fundamental nature of these changes is essential for designing policies with a chance of success in the European countries, which together with the US have seen the most dramatic upheaval of their previously successful production fabric.

The most extensive job losses in USA manufacturing did not occur after the 2007-08 collapse but during the easy credit bubble. Those were the years of the massive shift of production to Asia. Manufacturing employment in the US fluctuated at around 18 million from the mid-1960s to 2000, then dropped by over one-third, from 17 million to 13 million, in the seven years of the easy credit boom. Those jobs are not recoverable except through high-tech redesign of a segment of the products involved and/or with the creation of non-offshorable segments in the economy. The rental economy in the durable goods sector could create hundreds of thousands of jobs in maintenance and distribution, but a return to high growth and high-quality lives will only come by inducing bold innovation and new technology systems.

Although the phenomenon may be less acute in some European countries than in the US, it is of the same nature. In the UK, for instance, there was a greater intensity of job losses in manufacturing during the NASDAQ boom of the 2000s (1 million, or 25 percent) than during the current recession (nearly half a million). Thus, it is essential to recognise that technological or globalisation job losses cannot be recovered with economic 'revival'. Only large-scale innovation can replace these jobs with new ones. And thanks to the MIT project Production in the Innovation Economy (MIT, 2013), it can now be said - with abundant empirical evidence - that without domestic manufacturing activities and capabilities, innovation cannot be turned into production and jobs. It is time to seriously rethink active respecialisation.

New jobs will not be brought about by maintaining austerity policies or by providing stimulus via the banks. It is only through a major innovation effort, which increases both public and private sector commitments to long-run investments in human capital, R\&D and infrastructure, that we can begin to engage in a dialogue in which innovation and employment are not seen as trade-offs. There is nothing 'natural' about 'secular stagnation' (Summers, 2013); it is not an exogenous fate but an endogenous outcome of the lack of investments being made and the lack of an innovation direction being chosen.

Apart from the employment shifts brought by technological revolutions, there is also a strong polarisation of income. This is directly linked to the intense financialisation of the economy that has historically accompanied the initial decades of diffusion and the resultant major technology bubbles (Perez, 2002, 2009, 2013). Long-term data gathered by Piketty and Saez (2010) on US income distribution among taxpayers shows how similar the polarisation in the recent bubbles is to that of the 'roaring twenties' (see Figure 5). Both periods of extreme income inequality are in stark contrast with the resulting reversal in the post-war boom, when suburbanisation, the Cold War and mass 
production innovation brought jobs and growth, while labour unions, the tax structure and the welfare state ensured that the incomes of the majority of citizens increased with productivity. Sociopolitical choices can make a huge difference.

Figure 5 How financialisation polarises income during bubbles.

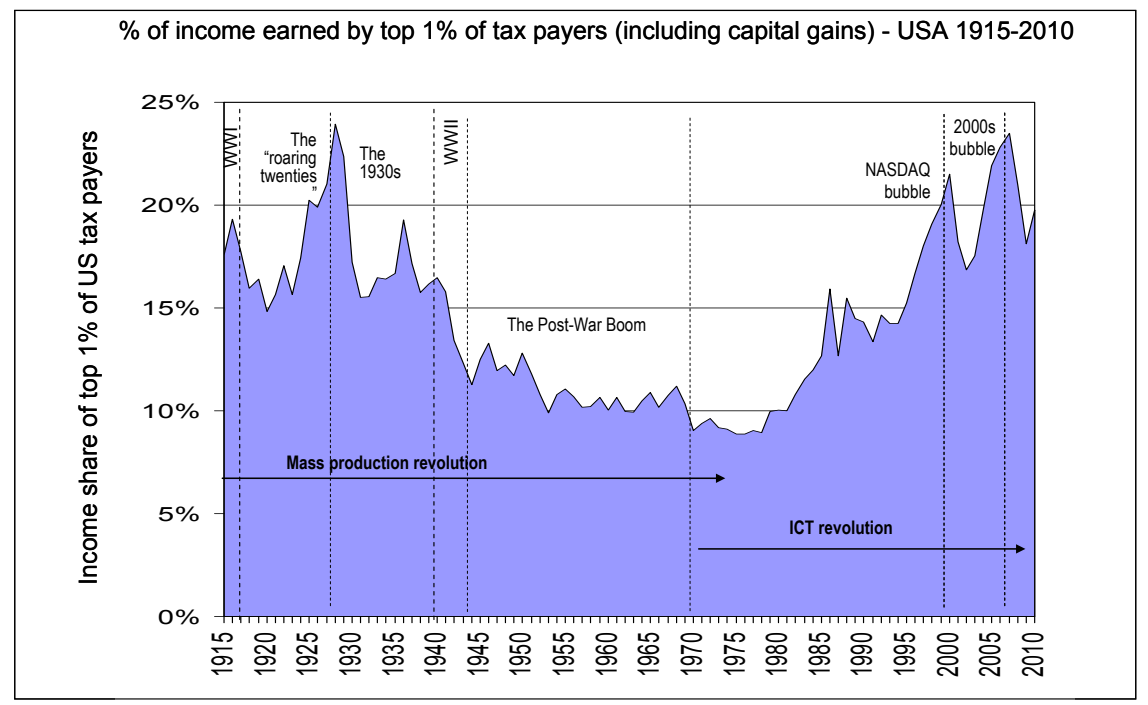

Source: Piketty and Saez 2010 (period indications ours).

Lazonick and Mazzucato (2013) argued that inequality of such an extreme form has to do with the ability of some agents in the economy - specifically the financial ones - to 'extract' value from the innovation process. Hence, the problem of inequality (regardless of whether Piketty's (2014) wealth tax proposal is applied) needs to be faced directly by innovation/industrial policy. It is no use arguing that skill changes are the source of the current inequality. Skills are 'endogenous' to the investment process (that is, skills are actively created and are not manna from heaven). Therefore, it is necessary to make sure that all investment, and especially public-private partnerships, increase rather than decrease the incentives of private companies to invest in human capital formation, and other long-term areas like research and development. ${ }^{10}$

It is clear that unless industrial policy also asks what kind of innovation eco-systems we want, we risk creating ones that are not symbiotic but parasitic, in which a disproportionate share of the rewards from innovation go to a narrow group of actors, who call themselves the great value creators but are in reality the great value extractors; again, this is a problem tied to the financialisation of the economy.

\section{7) Smart innovation requires smart government}

\footnotetext{
${ }^{10}$ The risk is that the 'open innovation' model has increased the number of alliances, but not enhanced the degree of commitment needed by each of the partners involved. In the US in pharmaceuticals, for example, as the State has stepped up its role in the research element of R\&D, the private sector has decreased its support, dedicating more of its retained earnings to development (D), marketing, take-overs and stock buybacks.
} 
Understanding the problem and the nature of the solutions is only a first, albeit indispensable, step. Implementing the necessary directionality also requires effective public actors, and this requires sector and technology-specific expertise to be located in government so that public interventions are not just making it easier (via subsidies) but also raising the stakes and commitment by all and 'making things happen that otherwise would not' (Keynes, 1936). Government must not only fund innovation but also to innovate 'within'. One of the most important innovations introduced by government during the Victorian boom in the 1850 s was the introduction of exams for entering the civil service (Cohen, 1941). It was the knowledgeable and meritocratic structure of the British government that allowed such a small country to effectively govern an empire that covered a third of the planet. Before that, posts in the civil service had been bought or granted. Today, many public servants are as competent and highly educated as top managers in private companies (as are many politicians), but as long as governments are presented as boring bureaucracies that get in the way of the creative people, they will not bring forth existing talent or be able to attract new talent, which is precisely what is needed in the areas that drive growth.

Another necessary change refers to the ways of measuring and judging performance. Governments, like innovative companies, must welcome rather than fear the failures that are inevitable when undertaking uncertain innovations. Those countries that are currently growing through innovation, such as China, Brazil, Finland and Singapore, have expertise in innovation within top levels of government, not just in the ministries for innovation and industry. They have also set up dynamic agencies that are willing to explore in a trial-and-error process. Obama's active post-crisis stimulus programme (until 2010) was heavily influenced by a Nobel Prize laureate scientist, Steve Chu, in the Department of Energy, who was responsible for setting up ARPA-E (Grunwald, 2012). BNDES, Brazil's active and successful state investment bank, which has doubled its lending since the crisis, is directing investments not only in infrastructure but also in key sectors like pharma, biotech and clean-tech; and it is run by two non-neoclassical innovation economists. By contrast, when the State is filled with a fear of 'picking winners' and industrial policy is side-lined by the treasury, there is almost a self-fulfilling prophecy that leads to failure, with agencies responsible for industrial policy becoming marginal to the economic strategy and ending up with a patchy innovation policy that is at odds with macro growth policy.

\section{8) Conclusion - Towards a new European competitiveness}

We have argued that the current recession cannot be treated as an ordinary one, in which the economy can be revived through fiscal and monetary policy and, in this case, with financial reform. Europe (and indeed the world) is at a crossroads similar to the 1930s, with major institutional innovations needed to overcome a distorted financialised economy and a society with profoundly polarised incomes. As on that occasion, huge innovation potential must be turned into profitable opportunities, while creating the conditions for a fairer social sharing of the benefits.

We have also argued that in order for innovation-led growth to occur, an understanding of how innovation comes about must lead both financial reform and macro growth policy. Smart and 
inclusive growth must be government-led and innovation-driven, as it has been in the past. It must also go hand-in-hand with changes in corporate governance, which provide better incentives for companies to reinvest their profits in long-run value creation areas like human capital and R\&D. Furthermore, government policy must be understood as not only fixing markets but actively shaping and creating them. This requires providing a clear direction for innovation, investing in it and providing a coherent set of policies (direct and indirect) to tilt the playing field so that it rewards those firms that are willing and able to invest in the opportunities of the future. Secular stagnation is in no way inevitable; it is a result of (endogenous) choices that are the opposite of the ones we have outlined below.

Our policy criteria can be summarised as follows:

1. Public investments as mission/challenge-oriented. It is important for innovation policy to be guided more by the need to actively shape and create markets than just to fix market failures or to compensate for imperfect information. This means the ability to catalyse many sectors under big 'challenges' (such as tackling climate change, or limits to natural resources or the ageing crisis). It also means having an overview of the support needed along the entire innovation chain, not just the clear public good areas.

2. Direct and indirect. It is unrealistic to think that tax incentives (indirect public spending) alone will work, because business investment is driven by perceptions of opportunities, not just cost. Such opportunities are often created through direct public investments in high-risk areas, into which the private sector is still too risk-averse to enter. As was the case with the ICT revolution, innovation must be directed along the entire chain, from basic research, applied research and early-stage financing of companies. This also requires admitting that the real crisis in Europe, especially amongst the weakest nations, is an investment crisis. While structural reforms are necessary, unless the weakest countries massively increase their investments, labour market reforms and liberalisation will have no effect except to redistribute income - regressively.

3. Use the EU banks to cure the investment crisis. Once it has been admitted that a key problem causing skewed competitiveness across Europe is the lack of investment in the periphery, the fiscal compact must be restructured to allow such investments rather than to dissuade them. This can be done both nationally and transnationally. The current diagnosis of the problem as one of 'too much debt', rather than one of 'too little strategic spending' is putting breaks on the EIB, precisely when it could be used to kick-start innovation-led growth and provide patient capital in the way that national development banks do in various countries (including the German $\mathrm{KfW}$ ). The ECB should be ready to step in with its moneycreating power to provide bonds that are co-financed with the EIB. 
4. Green as key challenge and redirection. The 'green transformation' will only occur if such directed challenge/mission-oriented investments can be geared towards green (as defined in section 4). If sustainable growth is the ambition of EC 2020, it is important to understand that this direction will be chosen by policy, not by markets with the required intensity. This is not about picking specific technologies or firms, but considering the portfolio of different investments, direct and indirect, that must be made to actively influence production and consumption patterns to reverse the energy- and materials-intensive model inherited from mass production - in other words, effecting a complete redirection of the entire economy. The mass production revolution required such directionality, and green growth is an option in which ICT can be used to enable convergent innovations across the entire economy today. However, this revolution requires a firm push from both supply and demand. Supply in the sense of direct mission-oriented investment in research, development and tax subsidies that make it clearly profitable to invest in renewable energies, special materials, conservation, recyclability, productivity of resources and so on. Demand in terms of fostering changes in consumer behaviour and stimulating the development of the lagging countries, whose markets for appropriate technology for infrastructure and capital goods can become a positive-sum game with the advanced world. Given that advanced countries cannot compete in cheap-labour, low-value products or services, it is essential to define - or create - high-quality, high-value demand areas.

5. Finance: quality not quantity. While it is often assumed that innovation requires finance, the nature of this financing is often overlooked. With its increasingly short-termist goals, the VC model can only play a limited role. Growth-driving innovation requires long-term committed capital. Public development banks are financing up to 34 percent of worldwide renewable energy projects, compared to only 19 percent for corporate actors (Mazzucato and Penna, 2014). It is important for finance policy to consider the different forms of patient long-term committed capital that are required, and also to accept the high failure rates that this might entail. Equally, when public funds take the form of public venture capital, it should be possible to benefit from the upside, so that losses can be covered and the next round supported via a 'revolving fund'. This would also render investment more 'social', as called for by Keynes: 'Socialization of investments helps to replan the environment of our daily life [...] Not only shall we come to possess these excellent [technological] things, but [...] we can hope to keep employment good for many years to come' (Keynes 1980:1946).

6. Definancialisation. Achieving this goal requires a dual emphasis. The total value added of the non-financial sector must be increased by inducing finance to lend not to itself but to valuecreating projects in the real economy, and to definancialise the real economy by incentivising firms to reinvest profits in areas like human capital, equipment, software and $R \& D$, rather than speculative areas that only aim to boost share prices (such as share buybacks) or find a way to limit those practices. 
7. Regulation for shifting profitability. While it is often argued that EU businesses are impeded by red tape, such claims miss the key point, emphasised by Polanyi (1944), that markets are always regulated, deeply embedded in political processes. The question is how they are regulated and for what purpose. Intelligent regulation (including taxation) can shift profitability towards innovation-led growth that serves the public good, which in turn can stimulate further innovation. For example, a rule that requires returning a product on disposal (as the EU directive on electrical and electronic goods does (European Union, 2012)) stimulates redesign for disassembly and recycling, rewarding the most successful designs and reducing the cost to the community. Planning rules in cities and environmental regulation of the construction industry for minimising energy consumption and maintenance will enhance the value of the properties and reduce running costs. Restricting industrial effluents can lead to 'industrial symbiosis' (Chertow, 2000), where one industry profits from using the by-products of another. Once there is a stable and consistent direction - such as 'green growth' can have - both regulation and innovation will tend to converge along a known trajectory and the policy maker's criteria can coincide with those of the business strategist.

8. Taxation. Crucial in the design of an innovation and growth strategy will be a radical and bold restructuring of the tax system. Tax structures must reward long-run investments - in labour and areas like R\&D - rather than quick trades that are geared at value extraction and lead to asset inflation. ${ }^{11}$ If well designed, a modernised tax system would discourage casinotype financial activities, reduce the advantage of high-frequency trading, radically decrease global tax avoidance, penalise resource use while reducing the tax on labour, and favour patient capital as well as investment in the real economy. Such an innovation-prone tax system is likely to include a 'financial transactions' tax, an increased capital gains tax (with a decreasing scale in time), a shift of taxes from salaries to energy and materials use, and policies that focus on stimulating R\&D and human capital formation.

The ideas behind the policies formulated since the financial collapse of 2007-08have not contributed greatly to reviving the European economies, restoring decent employment levels or reversing income polarisation. The time has come for a serious rethinking of both the policies and the premises behind them. Understanding innovation as a driver of growth, employment and wellbeing, and recognising the essential role of the State in innovating, creating new markets, stimulating and giving direction to innovation, is the essential foundation for a strategic redesign. In order for there to be a real chance of success, growth policy must be innovation policy.

\footnotetext{
${ }^{11}$ Interestingly, the Netherlands has recently introduced an innovative R\&D tax credit that, rather than targeting research income (which is easy to fudge), targets research labour (Lockshin and Mohnen 2012) - going precisely in this (correct) direction and emphasising the recognition of human capital as the sort of investment that should be encouraged.
} 


\section{References}

Acemoglu, D. (2002) 'Technical Change, Inequality and the Labor Market', Journal of Economic Literature 40:1, $7-72$.

Alessandri, P. and Haldane, A. (2009) Banking on the State, Bank of England, November 2009.

Amsden, A.H. (1989) Asia's next giant: South Korea and Late Industrialization, New York, Oxford University Press.

Block, F.L. and Keller, M.R. (eds.) (2011a) State of innovation: The U.S. government's role in technology development. Boulder, Colorado: Paradigm Publishers.

Block, F.L. and Keller, M.R. (2012) 'Explaining the transformation in the US innovation system: The impact of a small government program.' Socio-Economic Review [online] (30th September 2012) 1-28 (doi:10.1093/ser/mws021). Available from: http://ser.oxfordjournals.org/content/early/2012/09/30/ser.mws021.full.pdf+html [accessed 13.02.13]

Boyer, R. (2000) 'Is a Finance-Led Growth Regime a Viable Alternative to Fordism? A Preliminary Analysis,' Economy and Society, 29:1, 111-145.

Breakthrough Institute (2010) 'Where good technologies come from: Case studies in American innovation'. [online] Oakland, California: Breakthrough Institute, December. Available from: http://thebreakthrough.org/blog/Case\%20Studies\%20in\%20American\%20Innovation\%20report.pdf [accessed 24.01.13]

Brynjolfsson, E. and McAfee, A. (2011) Race Against The Machine: How the Digital Revolution is Accelerating Innovation, Driving Productivity, and Irreversibly Transforming Employment and the Economy. Digital Frontier Press.

Chertow, M. R. (2000) 'Industrial symbiosis: literature and taxonomy.' Annual Review of Energy and the Environment 25:1, 313-337.

Cohen, E.W. (1941), The Growth of the British Civil Service, 1780-1939, London: Allen and Unwin ).

Christensen C M. and van Bever, D. (2014) 'The Capitalist's dilemma', Harvard Business Review 92:6, 60-68.

David, P.A. (2004) 'Understanding the emergence of open science institutions: Functionalist economics in historical context.' Industrial and Corporate Change 13:4, 571-589.

Derthick, M. and Quirk, P.J. (1985) The Politics of Deregulation, Washington, D.C., Brookings Institution Press.

Dore, R. (2008) 'Financialization of the Global Economy', Industrial and Corporate Change 17:6, 1097-1112.

Dosi G., Freeman C., Nelson R.R., Silverberg G. and Soete L. (eds.). (1988), Technical Change and Economic Theory, London: Pinter.

Dosi, G. and Nelson, R. (1994), 'An Introduction to Evolutionary Theories in Economics', Journal of Evolutionary Economics, 4:3, 153-172.

Dosi, G. Fagiolo, G., \& Roventini, A. (2010) 'Schumpeter Meeting Keynes: A Policy-Friendly Model of Endogenous Growth and Business Cycles', Journal of Economic Dynamics and Growth 34, 1748-1767.

Dosi, G. and Lovallo, D. (2007) 'Rational entrepreneurs or optimistic martyrs? Some considerations on technological regimes, corporate entries, and the evolutionary role of decision biases', in Garud et al., eds. Technological Innovation: Oversights and Foresights Cambridge: Cambridge University Press, pp. 41-68.

Dosi, G, Llerena, P. and Labini, M.S. (2006) 'The relationships between science, technologies and their industrial exploitation: an illustration through the myths and realities of the so-called 'European Paradox." Research Policy 35:10, 1450-1464.

El Haggar, S. (2010) Sustainable industrial design and waste management: cradle-to-cradle for sustainable development. Academic Press.

Ellen MacArthur Foundation (2012/2013) Towards the circular economy. Economic and business rationale for an accelerated transition, Circular Economy Report Vol. $1 \& 2$. 
European Commission (2011) Social Situation Monitor, EU-SILC 2005-2011, Available from: http://ec.europa.eu/social/main.jsp?catld=1050\&intPageld=1871\&langld=en [accessed 11.04.14]

European Union (2012) Directive 2012/19/EU of the European Parliament and of the Council of 4 July 2012 on waste electrical and electronic equipment (WEEE), in the Official Journal of the European Union, L 197, 24 July 2012, Available from: http://eur-lex.europa.eu/legal-content/EN/TXT/?uri=OJ:L:2012:197:TOC [accessed 11.04.14]

Foray, D., Mowery, D.C. and Nelson, R.R. (2012) 'Public R\&D and Social Challenges: What lessons from mission R\&D programs?', Research Policy, 41:10 (December, 2012), 1697-1702.

Fredriksen, K. (2012) 'Income Inequality in the European Union', OECD Economics Department Working Papers, No. 952, OECD Publishing.

Freeman C. (1994) 'Innovation and Growth' in Dodgson and Rothwell (eds.). Handbook of Industrial Innovation, pp. 78-93. Aldershot: Elgar.

Freeman, C. (2008) Systems of Innovation: Selected Essays in Evolutionary Economics. Cheltenham: Elgar.

Freeman, C. and Louçã, F. (2001) As time goes by: From the industrial revolutions to the information revolution. Oxford; New York, Oxford University Press.

Freeman, C. and Perez, C. (1988) 'Structural Crises of Adjustment: Business Cycles and Investment Behaviour' in Dosi et al. (eds.). Technical Change and Economic Theory. London, Pinter. pp. 38-66.

Freeman C. and Soete, L. (1994) Work for all or mass unemployment: Computerised technical change into the 21st Century. London: Pinter.

Gordon, R. (2012) 'Is U.S Economic Growth Over? Faltering Innovation Confronts The Six Headwinds', Working Paper 18315, National Bureau of Economic Research, August 2012. http://www.nber.org/papers/wl8315

Grunwald, M. (2012) The New New Deal: The Hidden Story of Change in the Obama Era. New York: Simon and Schuster.

Haldane, A. G. (2011) 'The Short Long', speech at the 29th Société Universitaire Européene de Recherches Financières Colloquium: New Paradigms in Money and Finance?, Brussels; Bank of England.

Janeway, W. (2013) Doing Capitalism in the innovation economy. Cambridge: C.U.P.

Kaldor, N. (1966). Causes of the Slow Growth in the United Kingdom. Cambridge: Cambridge University Press

Keynes, J.M. (1926) The end of laissez-faire. London: L \& V Woolf.

Keynes, J.M. (1930:1931) 'The Grand Slump of 1930', in Essays in Persuasion (1972) The Collected Writings of John Maynard Keynes, vol. XI (1972) pp. 126-49. London: Macmillan for the Royal Economic Society

Keynes, J.M. (1936) The general theory of employment, interest and money. New York: Harcourt, Brace and Company.

Keynes, J.M. (1938) 'Private letter to Franklin Delano Roosevelt,' February 1st 1938. In Moggridge, D.E. (1992) Maynard Keynes: An economist's biography. London: Routledge.

Keynes, (1980) Activities 1940-46. 'Shaping the Post-War World: Employment and Commodities'. In: Moggridge, D. (ed.) Collected Works, v. XXVII. London: MacMillan.

Knight, F. (1921) Risk, uncertainty and profit. New York: Augustus M Kelley.

Krippner, G. R. (2005) 'The financialization of the American economy', Socio-Economic Review, 3:2, 173-208.

Lazonick, W. (2007) 'The U.S. stock market and the governance of innovative enterprise.' Industrial and Corporate Change 16:6, 983-1035.

Lazonick, W. (2009) Sustainable prosperity in the new economy?: Business organization and high-tech employment in the United States. WE Upjohn Institute.

Lazonick, W. and Mazzucato, M. (2013) 'Risks and rewards in the innovation-inequality relationship,' in Mazzucato, M. (ed), Industrial and Corporate Change, Special Issue on 'Finance, Innovation, and Growth'.

Lazonick, W., and O'Sullivan, M. (2000) 'Maximizing Shareholder Value: A New Ideology for Corporate Governance,' Economy and Society, 29, 1: 13-35. 
Lazonick, W. and Tulum, O. (2011) 'US biopharmaceutical finance and the sustainability of the biotech business model.' Research Policy 40:9 (November 2011), 1170-1187.

Lipsey, R., Carlaw, K. I. and Bekhar, C. T. (2005) Economic Transformations: General Purpose Technologies and Long-Term Economic Growth. Oxford University Press.

Lockshin, B. and Mohnen, P. (2012) 'Do R\&D Tax Incentives Lead to Higher Wages for R\&D Workers? Evidence from the Netherlands'. Maastricht Economic and Social Research Institute on Innovation and Technology (UNU-Merit) Working Paper no. 2012-058, 18 July; revised version of Working Paper no. 2008-034.

Lombardi, D.R. and Laybourn, P. (2012) 'Redefining Industrial Symbiosis', Journal of Industrial Ecology, 16:1, 28-37.

Lundvall, B-Å. (ed.) (1992) National innovation systems: Towards a theory of innovation and interactive learning. London: Pinter Publishers.

Mazzucato, M. (2012) 'Finance and innovation: reforming a dysfunctional system,' FINNOV Policy Brief 3 [online] Available from: http://www.finnovfp7.eu/sites/default/files/FINNOV\%20Policy\%20Brief\%20Feb\%201\%202012.pdf [accessed 11.04.14].

Mazzucato, M. (2013a) The Entrepreneurial State: debunking private vs. public sector myths, London: Anthem Press.

Mazzucato, M. (2013b) 'Finance, innovation and growth: finance for creative destruction vs. destructive creation,' in special issue of Industrial and Corporate Change, M. Mazzucato (ed.), 22:4: 869-901.

Mazzucato, M. and Penna, C. (2014) 'Beyond market failures: the role of state investment banks in the economy' Unpublished Working Paper.

Mazzucato, M. and Shipman, A. (2014) 'Accounting for productive investment and value creation,' Industrial and Corporate Change (January 14, 2014). Available from:

http://icc.oxfordjournals.org/content/early/2014/01/13/icc.dtt037.short?rss=1 [accessed 13.05.14]

McDonough, W. and Braungart, M. (2002) Cradle to Cradle: Remaking the Way We Make Things. New York: North Point Press.

MIT (Massachusetts Institute of Technology) (2013) A preview of the MIT production in the 'Innovation Economy Report', edited by Richard M. Locke and Rachel Wellhausen, mit.edu, 22 February. Available from: http:/web.mit. edu/press/images/documents/pie-report.pdf [accessed 25.02.13].

Mowery, D.C. (2010) 'Military R\&D and innovation.' In Handbook of the Economics of Innovation, Hall, B.H. and Rosenberg, N. (eds.) Chapter 29. Amsterdam: North-Holland.

Mowery, D.C., Nelson, R.R. and Martin, B.R. (2010) 'Technology Policy and Global Warming: Why New Policy Models Are Needed (or Why Putting New Wine in Old Bottles Won't Work)', Research Policy, 39, 10111023.

National Endowment for Science Technology and the Arts (2009) The vital 6 per cent: How high-growth innovative businesses generate prosperity and jobs. Research Summary. London: NESTA.

O'Sullivan, M. (2005) 'Finance and Innovation,' Chapter 9 in The Oxford Handbook of Innovation, eds. Jan Fagerberg, J., Mowery, D., Nelson, R.R., Oxford University Press.

Pavitt, K. (1984) 'Sectoral patterns of technical change: Towards a taxonomy and a theory.' Research Policy 13:6, 343-373.

Perez, C. (2002) Technological Revolutions and Financial Capital: The Dynamics of Bubbles and Golden Ages. Cheltenham: Edward Elgar.

Perez, C. (2009) 'The Double Bubble at the Turn of the Century: Technological Roots and Structural Implications', Cambridge Journal of Economics, 33:4, 779-805.

Perez C. (2013a) 'Financial bubbles, crises and the role of government in unleashing golden ages' in Pyka, A. and Burghof, H.P. (eds.) Innovation and Finance. London: Routledge

Perez, C. (2013b) 'Unleashing a golden age after the financial collapse: Drawing lessons from history', Environmental Innovation and Societal Transitions. 6, 9-23. 
Piketty T. and Saez E. (2010; update of 2003) Income Inequality in the United States, 1913-1998. The Quarterly Journal of Economics 115(1): 1-39. Available from: http://elsa.berkeley.edu/ saez/\#income [accessed 10.03.13].

Piketty, T (2013:2014) Capital in the 21st Century. Cambridge, MA: Harvard University Press.

Pisano, G.P. (2006) 'Can science be a business? Lessons from biotech.' Harvard Business Review 84:10, 114125.

Polanyi, K. (1944:2001) The great transformation: The political and economic origins of our time. Boston: Beacon.

Ricardo, D. (1817) On the Principles of Political Economy and Taxation. London: John Murray.

Rockström, J. et al. (2009) 'Planetary boundaries: exploring the safe operating space for humanity.' Ecology and Society 14:2, 32. [online] URL: http://www.ecologyandsociety.org/vol14/iss2/art32/

Romer, P. M. (1994) 'The Origins of Endogenous Growth'. The Journal of Economic Perspectives, 8(1), 3-22.

Rosenberg, N. (1983) Inside the Black Box: Technology and Economics. Cambridge: Cambridge University Press.

Sachs, J. (2014) 'We need a sixth wave of sustainable and green technologies', Green Week Conference 2014, European Commission, Brussels, June 3. Available from: http://cordis.europa.eu/news/rcn/36601_en.html [accessed 22.04.14].

Schumpeter, J. (1912:1961) The Theory of Economic Development, New York: Oxford University Press.

Schumpeter, J.A. (1939:1982) Business Cycles. Philadelphia: Porcupine Press.

Stirling, A. (2009) 'Direction, Distribution and Diversity: pluralising progress in innovation, sustainability and development', STEPS Working Paper 32, Brighton, STEPS Centre.

Summers, L. 'Why stagnation might prove to be the new normal,' Financial Times December 15, 2013. Available from: http://www.ft.com/cms/s/2/87cb15ea-5d1a-11e3-a55800144feabdc0.htm|\#axzz35Bf2xOBb [accessed 22.04.14].

Van Ark, B. (2001) The renewal of the old economy: An international comparative perspective, OECD Paris.

Varoufakis, Y., Holland, S. and Galbraith, J.K. (2013) 'A Modest Proposal for Resolving the Euro Crisis, Version 4.0' Available from: http://varoufakis.files.wordpress.com/2013/07/a-modest-proposal-for-resolving-theeurozone-crisis-version-4-0-final1.pdf [accessed 01.05.14]..

Verdoorn, J. P. (1949) 'On the Factors Determining the Growth of Labor Productivity,' in L. Pasinetti (ed.) (1993), Italian Economic Papers, Vol. II, Oxford: Oxford University Press.

Wade, R. (1990) Governing the Market: Economic Theory and the Role of Government in East Asian Industrialization. Princeton: Princeton University Press

Womack, J. P., Jones, D. T. and Roos, D. (1990) The Machine That Changed the World. New York: Rawson Associates.

Zenghelis, D. (2011) A macroeconomic plan for a green recovery. [www] Centre for Climate Change Economics and Policy, Grantham Research Institute on Climate Change and the Environment Policy Paper, January. Available from: http://www2.Ise.ac.uk/GranthamInstitute/publications/Policy/docs/PP_macroeconomicgreen-recovery_Jan11.pdf [accessed 01.05.14]. 


\title{
Recent papers in the SPRU Working Paper Series:
}

SWPS 2014-02. Florian Kern, Adrian Smith, Chris Shaw, Rob Raven and Bram Verhees. February 2014. "From laggard to leader: Explaining offshore wind developments in the UK."

SWPS 2014-03. Andy Stirling . March 2014. "Transforming Power: social science and the politics of energy choices."

SWPS 2014-04. Alex Coad, Gabriele Pellegrino and Maria Savona. March 2014. “Don't Stop Me Now: Barriers to innovation and firm productivity."

SWPS 2014-05. Antonio Messeni Petruzzelli, Vito Albino, and Daniele Rotolo. April 2014. "Determinants of Patent Citations in Biotechnology: An Analysis of Patent Influence Across the Industrial and Organizational Boundaries."

SWPS 2014-06. Andy Stirling. April 2014. "From Sustainability to Transformation: Dynamics and diversity in reflexive governance of vulnerability."

SWPS 2014-07. Ralitsa Petrova Hiteva and Tomas Maltby. April 2014. "Standing in the way by standing in the middle: the case of state-owned natural gas intermediaries in Bulgaria."

SWPS 2014-08. Sabine Hielscher and Adrian Smith. May 2014. "Community-based digital fabrication workshops: A review of the research literature."

SWPS 2014-09. José García-Quevedo, Gabriele Pellegrino and Maria Savona. May 2014. "Reviving demand-pull perspectives: The effect of demand uncertainty and stagnancy on R\&D strategy."

SWPS 2014-10. Daniele Rotolo, Ismael Rafols, Michael Hopkins, and Loet Leydesdorff. June 2014. "Scientometric Mapping as a Strategic Intelligence Tool for the Governance of Emerging Technologies."

SWPS 2014-11. Andy Stirling and Josie Coburn. June 2014. "Multicriteria Mapping Manual Version 1.0."

SWPS 2014-12. Anabel Marin, Lilia Stubrin and Patrick van Zwanenberg. June 2014. "Developing capabilities in the seed industry: which direction to follow?."

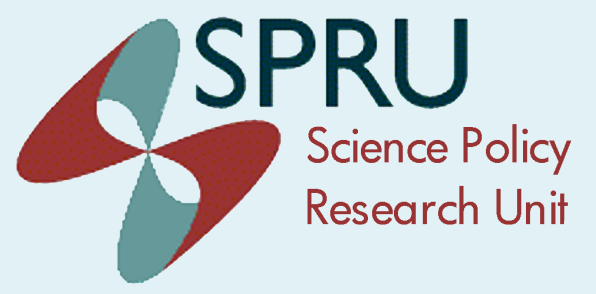

\author{
SPRU \\ Science Policy Research Unit \\ University of Sussex \\ Falmer, Brighton, BN1 9SL, UK \\ www.sussex.ac.uk/spru
}

